\title{
FOREIGN LANGUAGE ANXIETY EXPERIENCES OF FILIPINO STUDENTS ACROSS THE FOUR MACRO SKILLS
}

\author{
Gianinna Elaine Malapote Labicane \\ School of Arts and Sciences, Marinduque State College \\ Philippines \\ E-mail: gianinnalabicane@gmail.com
}

Received: 2021-05-25

Accepted: 2021-06-19

\begin{abstract}
Throughout the years, scholars have determined that foreign language learning is associated with negative emotional reactions rooted from communication apprehension, test anxiety, and fear of negative evaluation; a phenomenon more widely known as Foreign Language Anxiety (FLA), which has effectively hindered language learning for many students. Moreover, it does not help that the abrupt and drastic pedagogical transformations brought about by the COVID-19 pandemic in itself has proven to be stressful and anxiety-provoking for the learners. In this context, the aim of this study was to determine the foreign language anxiety experienced by Filipino learners in the remote learning setup. This mixed method study gathered data from 83 Filipino college students about their FLA experience across the four macro skills: reading, writing, listening and speaking amidst remote learning. Results revealed the participants experienced the highest level of anxiety with speaking. However, it must be noted that the fear of making mistakes and fear of negative evaluation can be observed across all the four macro-skills. Participants also struggle with opportunities to improve across the four macro skills due to the intermittent internet connection, inadequate resources, and limited interaction with their teachers and peers.
\end{abstract}

Keywords: Foreign Language Anxiety, Language Learning, Remote Learning

\section{Introduction}

The English language is widely recognized as one of the most powerful languages in the world being the language of economic advancement, academic pursuits, and globalization. Amid rapid international development, learning a language of such influence is needed to effectively cope with global competition. However, scholars over the years have recognized the anxiety-provoking potential that comes with learning the language; a phenomenon more popularly known as Foreign Language Anxiety (FLA). This is defined as negative emotional reactions associated with learning a foreign language and can be associated with the fear of communicating (communication apprehension), fear of tests, quizzes, and other forms of assessment (test anxiety), and worry over other people's perception of the learner (fear of negative evaluation) (Horwitz, Horwitz \& Cope, 1986). This phenomenon may be caused by lack of teacher engagemen, low proficiency, competition, an anxious personality, and pressure from peers, family, or even from oneself. While a considerable level of FLA may prove helpful in some language learning situations, it is more widely known for its negative 
effects on the learning process. FLA can be observed across all four macro-skills through what is referred to as skill-specific anxiety. While FLA is more often associated with listening (Otair \& Aziz, 2017; Hidayati, Dewi, Nurhaedin \& Rosmala, 2020; Sadiq, 2017 and Pan, 2016) and speaking (Dastpak \& Sadighi, 2017; and Bashori, van Hout, Strik \& Cucchiarini, 2020), researchers have found anxiety being felt in reading (Aydin, 2018; and Um, Tubsree \& Surasin, 2013) and writing (Choi, 2014; and Yayli, 2019) as well.

Over the years, there have been numerous researches proving how high levels of anxiety impede language learning (Um, Tubsree, Surasin, 2013; Boun, 2017; and Bollinger, 2017). However, there are only a few studies focused on the anxiety experienced by language learners in virtual environments. This is worth noting given how the COVID-19 pandemic led many academic institutions to resort to remote learning and the use of online platforms. Hence, this study aimed to determine language learners' level of Foreign Language Anxiety across the four macro-skills: reading, writing, listening, and speaking in the context of remote learning.

\section{Literature Review}

\subsection{Foreign Language Anxiety}

Foreign Language Anxiety is defined by Horwitz and Cope (1986) as a distinct complex of self-perceptions, beliefs, feelings, and behaviors related to language learning. While a certain level of anxiety may facilitate learning, this phenomenon is more known for its debilitating effects on learners (Donahoe, 2010). It can be observed in three different ways. FLA may be experienced through what is called communication apprehension, which happens when communicating with other people, either in speaking with others or in public or with receiving and understanding messages. Meanwhile, FLA may also come from a fear of failing to perform well in academic evaluations, known as test anxiety. It may also come from learners' expectations to be evaluated negatively, known as fear of negative evaluation.

FLA supports the second language acquisition theory by Krashen, particularly on the affective filter hypothesis, indicating a negative relationship between learners' anxiety levels and academic achievement. Students who experience high levels of anxiety often perform poorly using the language. Many researches over the years have shown the negative effect of anxiety on academic achievement. In a research by Subekti in 2018 on the relationship between the level of FLA and spoken performances of non-English major learners, a negative correlation was determined between the learners' performance and their comprehension apprehension, test anxiety, and fear of negative evaluation.

\subsection{Reading Anxiety}

Several researches over the years have explored foreign language anxiety among learners. A study on foreign language reading anxiety among Indonesian senior high school students revealed that most students experience a medium level of reading anxiety caused by unfamiliar vocabulary, topics, and culture. Other contributory factors include fear of making errors and concerns about reading effects (Muhlis, 2017). On the other hand, Zhou (2017) examined the foreign language reading anxiety of 76 students in the United States. Similarly, to Muhlis (2017), the participants also experienced a medium level of reading anxiety. It was also determined that poor comprehension skills, unfamiliar topics, and discomfort with reading aloud were among the major factors causing foreign language reading anxiety. The same factors were cited by the participants of a study by Al-Sohbani 
(2018) on 106 Yemeni secondary school students as causes of their reading anxiety. They also added unfamiliarity with grammatical systems of the English language and English letters and symbols among the factors.

\subsection{Writing Anxiety}

English language learners may also experience anxiety when writing. In a 2020 study by Rabadi \& Rabadi on the writing anxiety of 684 medical students from Jordanian universities, it was determined that the participants experienced a high level of anxiety as a result of linguistic difficulties, insufficient practice, low confidence in their writing skills, and fear of assessments.

Researches also reveal how learners' writing anxiety affects their writing performance. In a study by Sabti, Rashid, and Nimehchisalem (2019) on the impact of writing anxiety, writing achievement motivation, and self-efficacy on the writing performance of 100 Iraqi EFL learners, results revealed a negative correlation between writing anxiety and performance, as well as anxiety and achievement motivation. In another study by Zhang in 2019 on learners' writing anxiety and pedagogical use of online resources, a possible solution for alleviating writing anxiety was determined through the use of resources based on systemic functional linguistics, or SFL.

\subsection{Listening Anxiety}

Listening refers to the process of the human brain receiving stimuli, attaching meaning, integrating the message into one's frame of reference, and deciding on the appropriate feedback. Given that $45 \%$ of our time spent communicating is used for listening, listening is an important means of acquiring a second language (El-dali, 2017).

However, researches have shown how anxiety is also experienced when listening. In a study by Otair \& Aziz (2017), the causes of listening anxiety of EFL Saudi learners were explored, and it was determined that the participants struggled with the nature of listening comprehension, struggling greatly with the speakers' accent, speed of speech, and with unfamiliar lexical items. Moreover, they found that the low proficiency of students greatly contributed to their anxiety in the EFL classroom. They were also able to determine that the classroom atmosphere was a contributory factor to listening anxiety. The noisy environment, alongside the atmosphere of competition and judgment of the learning environment, made students anxious and stressed. Similarly, Hidayati, Dewi, Nurhaedin, and Rosmala (2020) studied the listening anxiety of 97 Indonesian tertiary students, where they determined that $54.6 \%$ of the participants had high levels of anxiety attributed to the speech rate and unfamiliar vocabulary words. Meanwhile, a case study on English language learning anxiety of Saudi Arabian learners revealed that the length of listening materials, speakers' poor enunciation, speech rate, and unfamiliar accents caused them listening anxiety (Sadiq, 2017). Teachers' acknowledgment of anxiety issues and students' practice of use of English beyond academic settings were recommended.

A 2016 study by Pan emphasized the role of teachers and students on listening anxiety in the classroom. The traditional teacher-centered approach is considered among the main causes of anxiety, as the teacher is the sole and utmost authority in the classroom. A teachers' strict demeanor may intimidate students, whereas a more relaxed and laid-back personality lowers students' anxiety. The study encourages the conduct of pre-listening activities, such as background probing and warm-up activities, to help students better process the materials they will listen to. Furthermore, the choice of appropriate learning 
Foreign Language Anxiety Experiences of Filipino Students Across The Four Macro Skills, Gianinna Elaine Malapote Labicane

materials that also cater to the students' interests may be of great help. On the other hand, students are encouraged to improve or develop achievement motivation.

\subsection{Speaking Anxiety}

Oral production is considered by many language learners as the most anxiety-provoking of the four macro-skills (Hashemi, 2011; as cited by Lababidi, 2016). Researches such as that of Dastpak \& Sadighi (2017), Muna \& Fitriah (2019), and Toubot, Send \& Atan Abdullah (2018) explore the effect of foreign language speaking anxiety on the academic performance of language learners.

A study (Sadighi \& Dastpak, 20197) on the speaking anxiety of 154 Iranian English language learners conducted in 2017 revealed that poor vocabulary, fear of negative evaluation, fear of making mistakes, and lack of practice opportunities were among the factors that contributed to the learners' speaking anxiety. Moreover, some of the participants in the study reported dreading to be corrected by teachers when speaking, as it raises their anxiety. They also reported that there is little to no opportunity to practice English beyond the classroom, but stated that their use of social media somehow helps develop their English-speaking skills. Self-confidence also seems to be a major factor in speaking anxiety. A study of speaking anxiety among EFL Libyan English undergraduate students conducted in 2018 revealed that a sense of self-inadequacy affects confidence, which in turn affects oral production as well (Toubot, Seng, and Atan Abdullah, 2018).

\subsection{Remote Learning}

Remote learning is characterized by the delivery of learning through different technological platforms, with both the students and the instructors not being physically present in the traditional learning environment. Usually employing the use of Learning Management Systems (LMS) or other learning platforms, students participate in synchronous and asynchronous learning activities from the comfort and safety of their homes. Since face-to-face discussions were suspended prohibited to prevent the spread of COVID-19, educational institutions all over the world had little to no choice but to undergo major transformations in methods and platforms of teaching in an effort to ensure the continuous delivery of instruction amid the pandemic; one of which is the transition to remote learning.

As observed from the cited literature, there have been numerous researches proving how high levels of anxiety impede language learning (Um, Tubsree, Surasin, 2013; Boun, 2017; and Bollinger, 2017) in the conventional classroom setup. However, there are only a few studies focused on the anxiety experienced by language learners in the online context. This research gap calls for a need to conduct researches exploring the experiences of learners with skill-specific language anxiety, especially as the COVID-19 pandemic led most academic institutions to employ remote learning, integrating the use of learning management systems and other online platforms; hence, the conduct of this research.

\section{Research Method}

This mixed methods study aimed to determine the levels of Foreign Language Anxiety experienced by learners in remote learning across reading, writing, listening, and speaking by gathering quantitative data through their agreement with the statements corresponding to skill-specific language anxiety. Moreover, qualitative data was also gathered to probe into the causes and nature of the participants' anxiety they experience in learning the language 
across the four macro skills. The participants of this study are the 81 first-year Bachelor of Science in Nursing students currently enrolled in the Marinduque State College for the 2nd Semester, Academic Year 2020-2021. Their enrollment in General Education courses, which include Purposive Communication, was the basis for their selection as participants for this study.

This research used a Google forms survey questionnaire, with items adapted from Serraj and Noordin (2013) to measure listening anxiety, Al-Shboul, Ahmad, Nordin \& Rahman (2013) for reading anxiety, Zhang (2011) for writing anxiety and Yaikhong \& Usaha (2012) for speaking anxiety. Using a 4-point Likert scale, (strongly disagree, disagree somewhat, agree somewhat, strongly agree), the participants were asked regarding their agreement to statements about their experiences with skill-specific language anxiety. The instrument also included open-ended questions to encourage the participants to describe their levels of anxiety more accurately.

Quantitative data gathered from the participants were subjected to tabulation, statistical analysis, and interpretation, while the qualitative data were thoroughly and repeatedly read and then analyzed through coding and identification of observable themes and patterns from the participants' responses.

\section{Results and Discussion}

Table 1. Participants' Level of Reading Anxiety

\begin{tabular}{|l|c|c|c|}
\hline \multicolumn{1}{|c|}{ Indicators } & $\begin{array}{c}\text { Weighted } \\
\text { Mean }\end{array}$ & $\begin{array}{c}\text { Verbal } \\
\text { Description }\end{array}$ & Rank \\
\hline $\begin{array}{l}\text { 1. When I am reading in English, I get frustrated whenever I encounter } \\
\text { unfamiliar vocabulary. }\end{array}$ & 2.77 & Agree & 5 \\
\hline $\begin{array}{l}\text { 2. I do not like to read an English text that has lots of difficult words. } \\
\text { English texts. }\end{array}$ & 2.42 & Disagree & 8 \\
\hline $\begin{array}{l}\text { 3. It bothers me to encounter words I can't pronounce while reading } \\
\text { language. }\end{array}$ & 2.85 & Agree & 2.5 \\
\hline $\begin{array}{l}\text { 5. I feel anxious when I am reading a topic in the English language } \\
\text { which I have no idea about. }\end{array}$ & 2.26 & Disagree & 10 \\
\hline 6. I feel anxious in reading aloud in fear of making errors. & Agree & 6 \\
\hline 7. I prefer silent reading rather than reading aloud. & 2.61 & Agree & 4 \\
\hline $\begin{array}{l}\text { 8. I get upset when I am not sure whether I understand what I am } \\
\text { reading in English or not. }\end{array}$ & 2.86 & Agree & 2.5 \\
\hline 9. English culture and ideas seem very foreign to me. & 2.30 & Disagree & 1 \\
\hline $\begin{array}{l}\text { 10. When reading English, I often understand the words but still can't } \\
\text { quite understand what the author is saying. }\end{array}$ & 2.57 & Agree & 7 \\
\hline \multicolumn{1}{|c|}{ TOTAL: } & 2.63 & & 9 \\
\hline
\end{tabular}

The table above shows the foreign language reading anxiety experienced by the participants. The results show that participants experience most anxiety when attempting to comprehend reading passages written in the English language. Participants also stated feeling anxious when coming across words with pronunciations they are unfamiliar with, which may be directly related to the participants' preference of silent reading over reading aloud. These results are consistent with that of Muhlis (2017) and Al-Sohbani (2018), wherein unfamiliar vocabulary items were among the factors causing reading anxiety. Students are often afraid of making errors in pronunciation and being criticized by peers and teachers when reading passages out loud. Muhlis further states that this fear of making 
Foreign Language Anxiety Experiences of Filipino Students Across The Four Macro Skills, Gianinna Elaine Malapote Labicane

errors may be the result of establishing a learning environment that lacks tolerance for making mistakes, which then increases students' reading anxiety.

The students' difficulties to comprehend English reading passages also support the findings of a study by Tien (2017) on the reading anxiety of 98 Taiwanese English-major students, wherein it was determined that reading comprehension is among the top concerns of students experiencing anxiety. With remote learning, this study's participants reported sometimes struggling to understand modules sent by their teachers, particularly when the writing style or the topic itself is too advanced or complex. They also reported encountering unfamiliar vocabulary items. This, therefore, calls for opportunities to process and discuss the topics in the modules with their teachers, as it would serve as an avenue for the students to clarify concepts they may struggle with.

Table 2. Participants' Level of Writing Anxiety

\begin{tabular}{|c|c|c|c|}
\hline Indicators & $\begin{array}{l}\text { Weighted } \\
\text { Mean }\end{array}$ & $\begin{array}{c}\text { Verbal } \\
\text { Description }\end{array}$ & Rank \\
\hline $\begin{array}{l}\text { 11. I am afraid that I might make grammatical mistakes in English } \\
\text { writing. }\end{array}$ & 3.25 & Agree & 1 \\
\hline 12. Grammar is too difficult in English writing. & 2.76 & Agree & 6.5 \\
\hline 13. I fail to come up with appropriate English words. & 2.55 & Agree & 9 \\
\hline $\begin{array}{l}\text { 14. I am afraid my peers or my teacher would make fun of my } \\
\text { mistakes in writing. }\end{array}$ & 2.76 & Agree & 6.5 \\
\hline 15. I could not express my ideas well in English. & 2.57 & Agree & 8 \\
\hline $\begin{array}{l}\text { 16. I feel stressed when I write English compositions under time } \\
\text { constraint. }\end{array}$ & 2.86 & Agree & 4 \\
\hline $\begin{array}{l}\text { 17. I'm afraid of my English composition being chosen as a sample } \\
\text { to be discussed in class. }\end{array}$ & 2.89 & Agree & 3 \\
\hline $\begin{array}{l}\text { 18. I'm not afraid at all that my English compositions would be } \\
\text { rated as very poor. }\end{array}$ & 2.41 & Disagree & 10 \\
\hline $\begin{array}{l}\text { 19. I don't think I have a good command of composition } \\
\text { techniques. For instance, I'm too much concerned about the } \\
\text { forms and formats. }\end{array}$ & 2.84 & Agree & 5 \\
\hline $\begin{array}{l}\text { 20. I worry at all about what other people would think of my } \\
\text { English compositions. }\end{array}$ & 3.00 & Agree & 2 \\
\hline $\begin{array}{ll} & \text { TOTAL: }\end{array}$ & 2.79 & & \\
\hline
\end{tabular}

Results in the Table 2 show that, in terms of writing anxiety, participants are mostly worried about making grammatical errors in their writing outputs. They are also concerned about how their compositions would be received by the readers, and that their teacher may use their writing output as a sample to be discussed in the class. This is consistent with the results of a study by Rabadi \& Rabadi (2020), wherein it was determined that the root cause of English language learners' writing anxiety is their poor linguistic knowledge. Students who have limited knowledge of grammatical rules and have poor vocabulary experience high levels of writing anxiety. Moreover, these results are also in agreement with that of Sabti, Rashid, and Nimehchisalem (2019), wherein students were highly concerned with how their peers would receive their writing outputs. This was also linked to why students attempt to avoid writing activities in English as much as possible.

Participants of the present study expressed that they are highly concerned with making grammatical and spelling errors in their writing outputs, and therefore worry that they would not be able to effectively convey their thoughts in writing. They also experience stress when they are unable to recall the English equivalent of a word. Aside from the mechanics of 
writing, the participants also expressed their worry over their writing organization skills. Some participants mentioned being unsure whether they can organize their ideas effectively in their writing outputs. For the aforementioned reasons, they worry over what the readers of their outputs, mainly their teachers or peers, would think about their work. Improving the students' writing difficulties is therefore needed to quell these anxieties. However, with the current learning setup, it may be more difficult now for teachers to provide immediate feedback to students regarding their writing outputs. While this may be done through the use of virtual platforms, the study also revealed unstable internet connection as one of the deterring factors.

Table 3. Participants' Level of Listening Anxiety

\begin{tabular}{|l|c|c|c|}
\hline \multicolumn{1}{|c|}{ Indicators } & $\begin{array}{c}\text { Weighted } \\
\text { Mean }\end{array}$ & $\begin{array}{c}\text { Verbal } \\
\text { Description }\end{array}$ & Rank \\
\hline $\begin{array}{l}\text { 21. It is difficult to understand people with English pronunciation } \\
\text { that is different from mine. }\end{array}$ & 2.38 & Disagree & 4 \\
\hline $\begin{array}{l}\text { 22. I worry that I might not be able to understand when people talk } \\
\text { too fast. }\end{array}$ & 2.85 & Agree & Agree \\
\hline $\begin{array}{l}\text { 23. I worry that I might have missed important information while I } \\
\text { was distracted. }\end{array}$ & 3.44 & Agree & 6 \\
\hline $\begin{array}{l}\text { 24. I am worried when I cannot see the lips or facial expressions of } \\
\text { the person. }\end{array}$ & 2.60 & Agree \\
\hline $\begin{array}{l}\text { 25. I get nervous and confused when I don't understand every word } \\
\text { in listening test situations. }\end{array}$ & 3.1 & Agree \\
\hline $\begin{array}{l}\text { 26. I feel uncomfortable listening without a chance to read the } \\
\text { transcript of the speech. }\end{array}$ & 2.84 & 5 \\
\hline $\begin{array}{l}\text { 27. It is difficult to concentrate on and hear a speaker I do not know } \\
\text { well. }\end{array}$ & 2.46 & Disagree & 7 \\
\hline $\begin{array}{l}\text { 28. My thoughts become jumbled and confused in listening for } \\
\text { important information. }\end{array}$ & 2.43 & Disagree & 8 \\
\hline $\begin{array}{l}\text { 29. I get worried when I have little time to think about what I have } \\
\text { heard. }\end{array}$ & 2.99 & Agree & 3 \\
\hline $\begin{array}{l}\text { 30. I am not very familiar with English stress and intonation } \\
\text { patterns. }\end{array}$ & 2.11 & Disagree & 10 \\
\hline \begin{tabular}{l} 
ToTAL: \\
\hline
\end{tabular} & 2.72 & & 3 \\
\hline
\end{tabular}

The table above shows the participants' listening anxiety, and results reveal that participants worry about missing important information while distracted from listening. They also expressed feeling anxious about hearing words that they are not familiar with and having limited time to process what they have just listened to. These results support researches by Hidayati, Dewi, Nurhaedin, and Rosmala (2020), where it was determined that language learners struggle with unfamiliar lexical items and speech rate. Adnan, Marlina, and Annisa's study in 2019 is also in agreement with the results of this research. They stated that learners may experience stress when encountering an unfamiliar word, which in turn leads to them being unable to comprehend the entire meaning of the listening material.

In their open-ended responses, the majority of the participants express struggling to listen and understand teachers who talk too fast, giving them little time to process what has just been said, or limited opportunities to clarify with the teacher either because of a time constraint or that they feel fearful of asking their teacher to clarify or repeat something unclear. In the context of remote learning, the participants' open-ended responses also revealed how they struggle with listening during virtual classes. They stated that there were 
Foreign Language Anxiety Experiences of Filipino Students Across The Four Macro Skills, Gianinna Elaine Malapote Labicane

several instances where the audio of a teacher during the discussion was inaudible or incomprehensible due to the unstable internet connection.

Table 4. Participants' Level of Speaking Anxiety

\begin{tabular}{|c|c|c|c|}
\hline Indicators & $\begin{array}{l}\text { Weighted } \\
\text { Mean }\end{array}$ & $\begin{array}{c}\text { Verbal } \\
\text { Description }\end{array}$ & Rank \\
\hline $\begin{array}{l}\text { 31. I tremble when knowing that I am going to be called on to } \\
\text { speak English. }\end{array}$ & 2.76 & Agree & 9 \\
\hline $\begin{array}{l}\text { 32. I start to panic when I have to speak English without } \\
\text { opportunity for preparation in advance. }\end{array}$ & 3.01 & Agree & 6 \\
\hline $\begin{array}{l}\text { 33. I feel very self-conscious while speaking English in front of } \\
\text { other students. }\end{array}$ & 3.18 & Agree & 3 \\
\hline $\begin{array}{l}\text { 34. I am afraid that other students will laugh at me while I am } \\
\text { speaking English. }\end{array}$ & 2.87 & Agree & 8 \\
\hline $\begin{array}{l}\text { 35. Certain parts of my body feel very tense and rigid while } \\
\text { speaking English. }\end{array}$ & 2.94 & Agree & 7 \\
\hline $\begin{array}{l}\text { 36. I am worried that my pronunciation of certain words is } \\
\text { incorrect. }\end{array}$ & 3.11 & Agree & 5 \\
\hline 37. I am afraid of making grammatical errors when I speak. & 3.27 & Agree & 1 \\
\hline $\begin{array}{l}\text { 38. I am worried about not having wide vocabulary when I } \\
\text { speak. }\end{array}$ & 3.24 & Agree & 2 \\
\hline $\begin{array}{l}\text { 39. I keep thinking that the other students are better at English } \\
\text { than I am. }\end{array}$ & 3.15 & Agree & 4 \\
\hline 40. I do not believe I can speak in English spontaneously. & 2.74 & Agree & 10 \\
\hline TOTAL: & 3.03 & & \\
\hline
\end{tabular}

In terms of speaking anxiety, results show that participants are mostly afraid of making grammatical errors. They also stated being worried about poor vocabulary, and of feeling self-conscious while speaking in English in front of other students. In their open-ended responses, the participants explained they fear being judged by their peers if they make grammatical errors when speaking. They also reported experiencing suddenly being at a loss for words when asked to speak in English. Furthermore, the majority of participants are also worried that they would be laughed at for not being able to speak English well. These research findings are consistent with that of Muna and Fitriah (2019), wherein it was found that students' high levels of speaking anxiety were caused by their poor vocabulary and unfamiliarity with grammar rules.

The findings of the present research are also in agreement with that of Sadighi \& Dastpak (2017), wherein it was determined that language learners' speaking anxiety came from their fear of making mistakes because of their poor vocabulary and their insufficient knowledge of English's grammatical rules. The students' fear of making mistakes and feeling of consciousness when being asked to speak in English in front of their peers may be rooted in a fear of negative evaluation. However, more concerningly, the lack of practice seems to be further emphasized by the pandemic; since the implementation of the remote learning setup. In a study by Karatas and Tuncer (2020), it was revealed that because most students are now learning through modules, there is more focus on the development of their reading and writing skills, and less emphasis on nurturing listening and speaking skills. While synchronous online classes are sometimes held and these could be an avenue to improve the two latter skills, the oral participation of every student during the discussion is not guaranteed given the limited time and poor connectivity usually experienced in these contexts. 


\section{Conclusion}

The COVID-19 pandemic has drastically transformed the pedagogical landscape, yet despite the new learning environment, the issue of foreign language anxiety remains and is even emphasized by the remote learning setup. This study revealed the participants experienced the highest level of anxiety with speaking, however, it must be noted that the fear of making mistakes and fear of negative evaluation can be observed across all the four macro-skills. Participants also struggle with opportunities to improve their skills due to the intermittent internet connection and limited interaction with their teachers. With these findings, teachers are encouraged to establish a learning environment that is free of judgment, where students' errors are viewed as simply a natural part of the learning process. Emphasis may be placed on improving knowledge of grammatical rules and expanding their vocabulary. Teachers are also encouraged to establish an improved channel of communication with their students and to provide them feedback on the practice of their skills. Since internet connection has been shown as a consistent problem, teachers may opt for alternatives that do not require much internet connection, such as downloadable prerecorded lectures. Students must also seek opportunities to improve their skills on their own, and are therefore encouraged to practice listening, reading, writing and speaking English beyond academic contexts.

\section{References}

Adnan, A., Marlina, L. \& Annisa, S. (2019). Listening Comprehension and Listening Anxiety: A Case of Basic Listening Class Students at English Department UNP Padang. Advances in Social Science, Education and Humanities Research, Vol. 411.

Al-Shboul, M., Ahmad, I. Nordin, M. \& Rahman, Z. (2013). Foreign Language Reading Anxiety in a Jordanian EFL Context: A Qualitative Study. English Language Teaching; Vol. 6, No. 6; 2013. ISSN 1916-4742 E-ISSN 1916-4750.

Al-Sohbani, Y. (2018). Foreign Language Reading Anxiety among Yemeni Secondary School Students. International Journal of English Language and Translation Studies. ISSN: 2308-5469.

Aydin, S. (2018). Technology and Foreign Language Anxiety: Implications for Practice and Future Research. Journal of Language and Linguistic Studies, 14(2), 193-211; 2018.

Bashori, M., Van Hout, R., Strik, H. \& Cucchiarini, C. (2020). Web-based Language Learning and Speaking Anxiety. Computer Assisted Language Learning. Computer Assisted Language Learning, DOI: 10.1080/09588221.2020.1770293.

Bollinger, A. (2017). Foreign Language Anxiety in Traditional and Distance Learning Foreign Language Classrooms. Virginia: Liberty University.

Boun, S. (2017). Social Psychological Impacts on Language Use: Anxiety among Cambodian University Students. TESOL International Journal. Vol. 12 Issue 2.

Choi, S. (2014). Language Anxiety in Second Language Writing: Is It Really A Stumbling Block?. Mānoa, Hawaii: University of Hawai 'i.

Dastpak, M. \& Sadighi, F. (2017). The Sources of Foreign Language Speaking Anxiety of Iranian English Language Learners. International Journal of Education \& Literacy Studies. ISSN: 2202-9478.

Donahoe, T. (2010). Language Anxiety in the Online Environment: An Exploratory Study of a Secondary Online Spanish Class. California: Pepperdine University.

El-dali, M. (2017). L2 Listening Comprehension: Is it a Language Problem or Listening Problem?. English Linguistics Research. Vol. 6, No. 1; 2017. 
Foreign Language Anxiety Experiences of Filipino Students Across The Four Macro Skills, Gianinna Elaine Malapote Labicane

Hashemi, M. (2011). Language Stress and Anxiety among the English Language Learners. Procedia - Social and Behavioral Sciences. 30:1811-1816. DOI: 10.1016/j.sbspro.2011.10.349

Hidayati, A., Dewi, N. Nurhaedin, E. \& Rosmala, D. (2020). Foreign Language Listening Anxiety in an Academic Listening Class. Journal of English for Academic. Vol. 7. No. 2.

Horwitz, E., Horwitz, M. and Cope, J. (1986). Foreign Language Classroom Anxiety. The Modern Language Journal, Vol. 70, No. 2 (Summer, 1986), pp. 125-132.

Karatas, T. \& Tuncer, H. (2020). Sustaining Language Skills Development of Pre-Service EFL Teachers despite the COVID-19 Interruption: A Case of Emergency Distance Education. Sustainability 2020, 12, 8188; doi: 10.3390/su12198188.

Lababidi, R. (2016). Language Anxiety: A Case Study of the Perceptions and Experiences of Students of English as a Foreign Language in a Higher Education Institution in the United Arab Emirates. English Language Teaching; Vol. 9, No. 9; 2016.

Muhlis, A. (2017). Foreign Language Reading Anxiety among Indonesian EFL Senior High School Students. English Franca Vol 1 No 01 Tahun 2017, STAIN Curup. P-ISSN 25803670, E-ISSN 2580-3689.

Muna, H. \& Fitriah. (2019). Foreign Language Speaking Anxiety: A Case Study at English Department Students of lain Lhokseumawe And Al Muslim University. Jurnal IImiah DIDAKTIKA Februari 2019. Vol. 19, No. 2, 140-158.

Otair, I. \& Aziz, N. (2017). Exploring the Causes of Listening Comprehension Anxiety from EFL Saudi Learners' Perspectives: A Pilot Study. Advances in Language and Literary Studies. ISSN: 2203-4714.

Rabadi, R. \& Rabadi, A. (2020). Do Medical Students Experience Writing Anxiety While Learning English as a Foreign Language?. Psychol Res Behav Manag. 2020; 13: 883893. Published online 2020 Oct 30. DOI: 10.2147/PRBM.S276448.

Sabti, A., Rashid, S. \& Nimehchisalem, V. (2019). The Impact of Writing Anxiety, Writing Achievement Motivation, and Writing Self-Efficacy on Writing Performance: A Correlational Study of Iraqi Tertiary EFL Learners. https://doi.org/10.1177/ 21582440 19894289.

Sadiq, J. (2017). Anxiety in English Language Learning: A Case Study of English Language Learners in Saudi Arabia. English Language Teaching; Vol. 10, No. 7; 2017.

Serraj, S. \& Noordin, N. (2013). Relationship among Iranian EFL Students' Foreign Language Anxiety, Foreign Language Listening Anxiety and Their Listening Comprehension. English Language Teaching; Vol. 6, No. 5; 2013.

Subekti, A. (2018). Investigating the Relationship between Foreign Language Anxiety and Oral Performance of Non-English Major University Students in Indonesia. Dinamika Ilmu. Vol. 18, No. 1, 2018. P-ISSN: 1411-3031; E-ISSN: 2442-9651. doi: http://dx.doi.org/10.21093/di.v18i1.880.

Tien, C. (2017). Factors of Foreign Language Reading Anxiety in a Taiwan EFL Higher Education Context. Journal of Applied Linguistics and Language Research. Volume 4, Issue 8, 2017, pp. 48-58.

Toubot, A., Seng, G. \& Atan Abdullah, A. (2018). Examining Levels and Factors of Speaking Anxiety among EFL Libyan English Undergraduate Students. International Journal of Applied Linguistics \& English Literature. E-ISSN: 2200-3452 \& P-ISSN: 2200-3592.

Um, S., Tubsree, C \& Surasin, J. (2013). Perception of English Reading Comprehension Anxiety of Third Year EFL Students at the Institute of Foreign Languages, Cambodia. HRD Journal. 4 (1), 34-46. 
Yaikhong, K. \& Usaha, S. (2012). A Measure of EFL Public Speaking Class Anxiety: Scale

Development and Preliminary Validation and Reliability. English Language Teaching; Vol. 5, No. 12; 2012.

Yayli, D. (2019). The Second Language Writing Anxiety: The Perceived Sources and Consequences. Pamukkale University Journal of Education · January 2019.

Zhou, J. (2017). Foreign Language Reading Anxiety in a Chinese as a Foreign Language Context. Reading in a Foreign Language. ISSN 1539-0578. April 2017, Volume 29, No. 1. pp. 155-173. 